\title{
LA ESPAÑA PENINSULAR Y LA NUEVA ESPAÑA ANTE LOS ACONTECIMIENTOS \\ DE 1808 (EL LIBERALISMO GADITANO Y LA INSURGENCIA NOVOHISPANA EN UNA ERA REVOLUCIONARIA)**
}

\author{
Roberto Breña \\ El Colegio de México
}

Cualquier imperfecta explicación que podamos ofrecer de lo que tuvo lugar antes de nuestro tiempo depende de las ventajas de la retrospectiva, incluso aunque ésta sea en sí misma un obstáculo insuperable para una completa empatía con la historia que estamos tratando de comprender.

Tony JUDT ${ }^{1}$

\begin{abstract}
T a revolución política que tuvo lugar en la España peninLular entre 1808 y 1814 y el proceso emancipador de la Nueva España son dos reacciones a una sola crisis: la que sufrió la Monarquía hispánica en la primavera de 1808. Fue entonces cuando la ocupación del territorio español por parte de las tropas del emperador Napoleón Bonaparte, que
\end{abstract}

Fecha de recepción: 18 de marzo de 2015

Fecha de aceptación: 7 de septiembre de 2015

* Agradezco a Virginia Guedea y a José María Portillo sus comentarios a una versión preliminar de este artículo.

${ }^{1}$ JudT, Elpeso..., 2014, p. 15. 
había tenido lugar durante el otoño de 1807, se transformó en una invasión en toda regla. El Tratado de Fontainebleau, firmado entre la corona española y el imperio francés a fines de octubre de 1807, había amparado el ingreso de las tropas francesas en territorio español. Su objetivo era apoderarse de Lisboa, pues Portugal era aliado de Inglaterra, la sempiterna enemiga de Francia; en principio, el territorio español era entonces sólo una vía de paso. Sin embargo, la paciencia del pueblo español respecto a un ejército que siempre se comportó como una fuerza de ocupación se agotó en Madrid en los primeros días de mayo de 1808, cuando se levantó contra las tropas francesas, con el apoyo de apenas un puñado de militares españoles. ${ }^{2}$

Estamos ante dos reacciones que en un primer momento tienen como común denominador la defensa de una serie de principios políticos y valores sociales que se pueden resumir en la expresión "rey, patria y religión". En la actualidad sabemos que los hechos que tuvieron lugar en la capital española los días 2 y 3 de mayo de 1808 no fueron los verdaderos detonadores de la crisis hispánica, sino la difusión en el territorio español peninsular de la noticia de que unos días después, el 5 de mayo concretamente, Fernando VII había renunciado a la corona en beneficio de su padre y que éste había cedido el trono español a Napoleón. Un mes después, el emperador de los franceses cedió la corona a su

${ }^{2}$ Este levantamiento fue inmortalizado por Goya en dos célebres cuadros (El 2 de mayo y Los fusilamientos del 3 de mayo; al primero se le conoce también como La carga de los mamelucos). Estos lienzos reflejan tanto el coraje del pueblo madrileño en su lucha contra el mejor ejército de la época como la magnitud de la represión que Joachim Murat, lugarteniente del emperador, puso en práctica en esa ocasión. 
hermano mayor José, quien el 7 de julio de 1808 se convirtió oficialmente en José I, rey de España e Indias. Esta serie de renuncias y cesiones es conocida como "las abdicaciones de Bayona”. ${ }^{3}$ Más allá de esta expresión, son estas renuncias las que provocaron las reuniones que tendrían lugar en la capital de la Nueva España en los meses de agosto y septiembre de 1808, presididas por el virrey José de Iturrigaray, para dilucidar la manera en que el virreinato debía reaccionar políticamente ante los acontecimientos europeos. ${ }^{4}$ Como es sabido, este intento por parte de varios criollos, apoyados de modo progresivo por el virrey, de guardar en depósito la soberanía de Fernando VII mediante la instauración de una asamblea representativa terminó con el "golpe de Estado" de los comerciantes peninsulares de la ciudad de México dirigidos por Gabriel de Yermo. A las propuestas criollas presentadas en estas reuniones se les ha

${ }^{3}$ Sin embargo, la única abdicación propiamente dicha es una que precede a estos acontecimientos: la que Carlos IV hizo en favor de su hijo Fernando en Aranjuez el 19 de marzo de 1808. Es ésta la abdicación que el propio Carlos IV no reconoció poco tiempo después, por haber sido forzado a ella, según su testimonio. Esto, aunado al conocimiento por parte de la familia real de los acontecimientos del 2 y 3 de mayo, fue lo que determinó que Fernando VII renunciara al trono apenas un mes y medio después de haber accedido a él (con la cascada de consecuencias que acabo de señalar). ${ }^{4}$ En el ámbito americano, en este artículo centraré mi atención en la Nueva España, pero conviene aclarar que, exceptuando el apoyo prácticamente unánime que recibió Fernando VII en todo el subcontinente ante los atropellos napoleónicos, las reacciones en los territorios americanos a la crisis iniciada en 1808 respondieron rápidamente a contextos sociopolíticos particulares. Por lo tanto, más allá de una serie de principios doctrinarios que fueron invocados de manera unánime por los hispanoamericanos, los contenidos, las connotaciones y los tempos de las respuestas americanas a los acontecimientos peninsulares se fueron diferenciando cada vez más. 
denominado una búsqueda de "autonomía”, un término que desde hace tiempo ha gozado de un notable predicamento en la historiografía, a tal grado que algunos autores lo usan como eje explicativo de todo el proceso emancipador novohispano (insurgente y no insurgente). ${ }^{5}$

A este respecto conviene hacer algunas aclaraciones. La primera es que el término "autonomía” no se empleaba en la época con la connotación que ahora se le adjudica. La segunda, más importante, es que detrás de un término que a menudo es utilizado de forma unívoca y aparentemente comprensible para todos (coetáneos de los acontecimientos y lectores actuales), lo que se dio en realidad fue un abanico muy amplio de maneras de entender el tipo de relación que los novohispanos querían o debían establecer con la metrópoli. En buena lógica, la distancia entre "autonomía" e "independencia" es más relativa de lo que podría pensarse, como lo muestran los acontecimientos que tuvieron lugar en la Nueva España a partir de 1820, concretamente la obtención de la independencia en septiembre de 1821 mediante un documento que en una de sus bases ofrecía la corona del nuevo país a Fernando VII. ${ }^{6}$ No se olvide, por lo demás, que

\footnotetext{
${ }^{5}$ El representante más conspicuo de esta manera de intentar otorgarle inteligibilidad al proceso emancipador novohispano en su conjunto es Jaime Rodríguez; la última reiteración de esta tesis es su libro RodRíGUEz, "Nosotros somos ahora los verdaderos españoles", que constituye la última interpretación global sobre la independencia de México. Tres años después apareció una versión revisada en inglés, en un solo volumen, que es más breve y cuyo subtítulo es algo distinto: "We are now the true spaniards".

${ }^{6}$ Por lo mismo, habría que ser más precavidos al plantear los términos "autonomía" e "independencia" como antitéticos y, en todo caso, aclararlos y matizarlos cuando optamos por emplearlos con fines heurísticos.
} 
los contextos políticos y discursivos en los que los diferentes actores empleaban el término "independencia" determinaban en gran medida su connotación y alcance. ${ }^{7}$

Respecto a este tema, cabe añadir que darle la importancia que merece al tema de la guerra en cualquier intento por explicar la independencia novohispana no supera el debate sobre los presupuestos y las implicaciones que podía tener la búsqueda de "autonomía" o de "independencia" en un momento dado. ${ }^{8}$ Una vez establecido el significado y alcance de uno $\mathrm{u}$ otro término para un actor determinado, esto tiene una serie de consecuencias respecto a otras facetas de este mismo actor, así como también respecto otros actores y al contexto políticoideológico del momento en cuestión. En el caso de Miguel Hidalgo, no es una cuestión menor saber si desde el principio de la insurrección que dirigió buscaba la independencia absoluta o algún tipo de arreglo dentro

7 En cuestiones historiográficas como ésta la utilidad de la historia de los lenguajes políticos y de la historia conceptual me parece evidente. Menciono en especial este aspecto porque algunos historiadores mexicanos se muestran escépticos ante las aportaciones que pueden hacer este tipo de enfoques, considerados por algunos como excesivamente teóricos.

${ }^{8}$ Por poner un ejemplo: en la nueva edición, corregida y aumentada, de su libro Guerra y gobierno, Juan Ortiz Escamilla, uno de los historiadores que ha adoptado una postura crítica respecto a los autores que desde su punto de vista hemos dado un peso excesivo al tema gaditano, no sólo no desecha la dicotomía autonomía/independencia (véase la p. 12), sino que recurre a ella o la presupone en algunas partes de su libro. La cuestión se complica aún más porque tanto en la introducción como en el capítulo III, titulado "La variante autonomista", el autor mezcla la "autonomía" del virreinato respecto a la metrópoli con el "autonomismo" de ayuntamientos y diputaciones provinciales dentro del mismo (planteamiento que puede confundir a algunos lectores respecto a una cuestión que ya es de por sí bastante compleja). El subtítulo del libro de Ortiz Escamilla, cuya edición original es de 1997, es Los pueblos y la independencia de México, 1808-1825. 
de la Monarquía española. Es por ello que Carlos Herrejón, en la que seguramente será la biografía "definitiva" de Hidalgo durante mucho tiempo, concede tanta importancia y tanto peso interpretativo a la hipótesis de que "el padre de la patria" propuso la independencia absoluta desde el primer momento; una hipótesis a la que Herrejón responde con una afirmación categórica. ${ }^{9}$

En cualquier caso, si el origen de los dos procesos considerados en este artículo es el mismo, sus desenlaces fueron muy distintos. Por un lado, en la Península los liberales españoles y su ambicioso proyecto político social serían derrotados por el absolutismo fernandino en mayo de 1814 . Por otro, en la Nueva España, un proceso que inició en 1810 como un movimiento de emancipación y que se transformó con relativa celeridad en la búsqueda de independencia absoluta (en el caso de la insurgencia), derivaría once años después en una separación muy peculiar del virreinato respecto a la metrópoli. Esta separación la llevó a cabo el militar realista Agustín de Iturbide bajo banderas ideológicas y sociales muy distintas de las que ampararon el levantamiento que encabezó Miguel Hidalgo en septiembre de 1810. Además, en claro contraste con lo sucedido en América del Sur, prácticamente no fueron necesarios enfrentamientos militares de envergadura para lograr la separación de España en septiembre de $1821 .{ }^{10}$

9 Véase Herrejón, Hidalgo, pp. 97, 244, 254, 257, 258, 268, 288, 289, 291, 353, 363, 441, 463, 472 y 514. En mi opinión, a pesar de la exhaustiva investigación de archivo realizada por el autor y de que varios de sus argumentos son atendibles, la cuestión sigue abierta.

10 Ésta es una de las diversas diferencias notables que existen entre el proceso 
Entre la insurrección de Hidalgo de 1810 y los acontecimientos de 1821, la insurgencia alcanzó alturas militares y constitucionales considerables con José María Morelos. Su fusilamiento en 1815 , sin embargo, hizo que la insurgencia menguara notablemente en términos políticos, y en lo militar se puede decir que se mantuvo en estado latente hasta la denominada "consumación". ${ }^{11}$ Ahora bien, como el historiador canadiense Christon Archer ha demostrado desde hace tiempo en múltiples textos, dicho estado no fue tan latente como se pensaba; lo que no significa, sin embargo, que la insurgencia haya representado una amenaza real para la estabilidad del virreinato en su conjunto entre 1815 y $1820 .^{12}$

Mientras tanto, durante esos mismos años es posible identificar en la metrópoli otro "estado de latencia": el que vivió el liberalismo español durante el llamado "sexenio absolutista" (1814-1820). Pienso concretamente en la serie de intentonas, pronunciamientos, conspiraciones y levantamientos que se dieron durante esos años para obligar al rey a volver a un régimen constitucional. ${ }^{13}$ Todos estos intentos

\footnotetext{
emancipador novohispano y los procesos sudamericanos. Los lectores interesados en estos contrastes pueden recurrir a mi artículo "The Emancipation Process in New Spain and the Cadiz Constitution”, pp. 42-62. ${ }^{11}$ Un sustantivo que, considerando lo que acabo de expresar sobre la enorme distancia entre los proyectos de Hidalgo e Iturbide, difícilmente puede considerarse apropiado. Volveré a esta cuestión más adelante.

12 Menciono sólo dos de los escritos de Archer a este respecto: "'La Causa Buena'”, pp. 85-108, y “La revolución militar de México”, pp. 123-176. ${ }^{13}$ El libro clásico sobre el tema es Fontana, La quiebra de la monarquía absoluta. Sobre ese mismo periodo en la Nueva España, José Antonio Serrano coordinó hace poco un libro dedicado al tema: SERrano, El sexenio absolutista.
} 
resultaron infructuosos, en buena medida por su escasa organización y el limitado apoyo social que obtuvieron. En todo caso, revelan una evidente intranquilidad del estamento militar con el régimen y en cierto sentido anuncian lo que sucedería en enero de 1820, cuando el teniente coronel Rafael de Riego se pronunció en la población andaluza de Las Cabezas de San Juan por el restablecimiento de la Constitución de Cádiz (al frente de tropas cuyo destino era América, pues el rey pretendía recuperar todos los territorios del subcontinente que hasta ese momento habían declarado su independencia). Dicho pronunciamiento, que en un principio pareció que también fracasaría, terminó siendo el origen de ese periodo de la historia española conocido como el "Trienio Liberal” (1820-1823). En relación con el proceso emancipador novohispano, esta vuelta del liberalismo a la Península significa algo que la historiografía mexicana tiende a ignorar: tanto la primera etapa de dicho proceso como su desenlace se dieron cuando lo que prevalecía políticamente en la metrópoli era el liberalismo (si bien, cabe añadir, en circunstancias realmente extraordinarias en lo que concierne al periodo gaditano, como explicitaré un poco más adelante).

A diferencia de lo acontecido en Cádiz diez años antes, en 1820 el liberalismo había llegado a España "por su propio pie”, por lo que cabía esperar que lograra cierto arraigo en la sociedad española y, por tanto, lograra extenderse en el tiempo. No fue el caso, pues poco más de tres años después de reinstalada la Constitución de Cádiz, el absolutismo fernandino volvió a triunfar, esta vez con el apoyo de la Santa Alianza, en concreto en Francia, la misma nación cuyas tropas se habían tenido que retirar menos de una década antes 
de la Península bajo el acoso del ejército angloespañol-portugués y de las guerrillas españolas. Curiosamente, el mismo pueblo que entonces había luchado a muerte contra el invasor francés entre 1808 y 1814, lo dejó pasar sin mayores problemas en 1823. En cualquier caso, por segunda ocasión en menos de diez años los liberales españoles eran vencidos por las fuerzas del absolutismo. ${ }^{14}$

Ahora bien, si en más de un sentido el Trienio Liberal se puede considerar parte de lo que algunos historiadores denominan el "primer liberalismo español", lo cierto es que lo acontecido durante esos tres años difícilmente se puede considerar una consecuencia directa de la crisis de 1808. Siendo así, y para volver a los temas centrales del presente artículo, ¿cuáles son algunos de los principales contrastes entre lo acontecido en la Península a raíz de dicha crisis y la reacción más visible y de mayores consecuencias en la Nueva España, es decir, el movimiento insurgente?

Uno de los aspectos más contrastantes es que la revolución política peninsular tuvo lugar en gran medida al amparo del liberalismo, una ideología que, más allá de sus ambigüedades e indeterminaciones, tuvo una serie de contornos bastante definidos cuando se le contrasta con la situación política que había imperado en la monarquía española

${ }^{14}$ En este caso, sin embargo, además del apoyo militar francés, las divisiones de los liberales son parte importante de la explicación de la victoria de Fernando VII. Otro elemento fundamental para explicar esta victoria fue la reacción de los generales del ejército español, quienes, exceptuando a Espoz y Mina, se vendieron al enemigo (en algunos casos de forma literal). Esto es lo que explica que en esta segunda invasión francesa no haya habido ni una sola gran batalla. Sobre la caída del Trienio, véase La PArra, Los cien mil hijos de San Luis. Hace un par de años apareció otro libro sobre el tema, LARRoche, L'expédition d'Espagne. 
hasta ese momento. Unos contornos que se desprenden, sobre todo, del hecho de que en el contexto peninsular la ideología liberal estaba determinada, en primer lugar, por un grupo político que se autodenominaba "liberal" y que así era conocido por sus enemigos políticos. ${ }^{15}$ No se puede decir nada parecido respecto al liberalismo en la América española. En este caso, la identificación del ideario liberal es bastante más complicada; los motivos son diversos. De entrada, una extensión geográfica desmesurada y, por tanto, situaciones políticas muy diversas. Prácticamente desde el inicio de la crisis hispánica el liberalismo adquirió perfiles peculiares en cada región del subcontinente, dependiendo de la situación política, social y económica en cada una de ellas. Con frecuencia, por cierto, esta situación estuvo más determinada por la relación entre regiones y ciudades dentro de cada entidad administrativa, que por una oposición a la corona española. Además, debe considerarse el origen eminentemente metropolitano del ideario liberal en la América española de la época, lo que explica también parte del rechazo a ciertas facetas del liberalismo, así como el hecho de que durante todo el proceso emancipador hispanoamericano no hubo ningún grupo político que se identificara a sí mismo como "liberal" o que reivindicara el liberalismo de manera explícita (tal como lo hicieron los liberales

${ }^{15}$ Pocos historiadores que no sean españoles o hispanoamericanos saben que el origen del término "liberal" para definir a un grupo político no está en Londres, Filadelfia o París, sino en Cádiz; esto sucedió hacia fines de 1810 en las cortes que se reunieron en ese puerto para redactar la que sería conocida como Constitución de Cádiz o Constitución de 1812. Existen unas cuantas excepciones a lo anterior; entre ellas destaco la de Eric Hobsbawm; véase su libro Echoes of the Marsellaise, p. 124, n. 56. 
peninsulares en las Cortes de Cádiz). Por último, a este respecto cabe insistir sobre la novedad lingüístico política del término para referirse a una ideología que estaba surgiendo en ese mismo momento histórico y que, por tanto, poseía una "escasa definición", por decirlo de algún modo.

En el caso concreto de la insurgencia novohispana, el hecho de que al frente de la primera insurgencia estuvieron dos sacerdotes es fundamental para explicar el tradicionalismo que la caracteriza en diversos ámbitos y que contribuye a explicar algunas de sus tensiones con el ideario liberal. ${ }^{16}$ Esto no significa, por cierto, que la insurgencia no fuera liberal en aspectos fundamentales; basta pensar en el Decreto constitucional para la libertad de la América mexicana, mejor conocido como "Constitución de Apatzingán”, pero me parece claro que la lucha insurgente fue una mezcla de elementos tradicionales y modernos que tuvo características ideológicas y doctrinales muy distintas respecto a la transformación política que dirigió un puñado de periodistas, abogados y eclesiásticos peninsulares entre 1810 y 1814 en el puerto de Cádiz. Es cierto que entre los grandes representantes de la revolución liberal peninsular se

${ }^{16}$ Esto se debe también a que la insurgencia novohispana fue no sólo un movimiento de provincia, sino eminentemente rural. Esto la coloca en claro contraste con la revolución gaditana, que, por motivos geográficos y militares (su carácter prácticamente inexpugnable bajo la protección de la armada británica), terminó por convertirse en un movimiento urbano. Eric van Young considera que el "ruralismo" del proceso emancipador novohispano lo distingue también de otras revoluciones atlánticas. Véase su ensayo "La época de la revolución atlántica”, en especial pp. 255-265. Van Young había planteado esta tesis en la conclusión de su libro, ya clásico, La otra rebelión; en esta edición, la traductora decidió emplear el término "ruralidad" (la versión original en inglés es de 2001). 
cuentan varios religiosos, algunos tan destacados como Diego Muñoz Torrero o José María Blanco White, pero la postura de ambos respecto a la política, a la relación de ésta con la vida social y respecto a la lucha que estaba teniendo lugar en aquel momento contra los franceses era profundamente distinta de la que defendían y propugnaban Hidalgo o Morelos en su contienda contra las autoridades virreinales. ${ }^{17}$

La insurgencia, pese a toda su importancia histórica e ideológica, no fue la única de las reacciones políticas que tuvieron lugar en el virreinato con motivo de la crisis que nos ocupa. De hecho, los cambios en la mentalidad política y en las propuestas sobre una nueva relación con la metrópoli por parte de los novohispanos comienzan con las reacciones inmediatas a la crisis de 1808 , esto es, preceden en más de dos años al movimiento insurgente; pienso, sobre todo, en fray Melchor de Talamantes y en Francisco Primo de Verdad y Ramos. Ahora bien, el descontento criollo en todo el virreinato respecto al "golpe de Estado" de los comerciantes peninsulares de la capital tomó formas diversas. Dado el carácter capitalino de esta ruptura de la legalidad, resulta hasta cierto punto lógico que las provincias se convirtieran en un terreno de cultivo más propicio para que se manifestara dicho descontento. Sin embargo, una de sus expresiones más relevantes tuvo su centro de operaciones en la Ciudad de México; me refiero a la agrupación clandestina

17 El tradicionalismo de ambos líderes insurgentes fue señalado hace tiempo por historiadores de la talla de David Brading y François-Xavier Guerra, por lo que resulta un tanto ocioso extenderse en este punto. De BRADING, véase Los orígenes del nacionalismo mexicano, pp. 76 y 82 y de Guerra, "La independencia de México y las revoluciones hispánicas”, pp. 15-16. 
conocida como "los Guadalupes", que estableció relaciones con varios líderes insurgentes, en particular con Morelos. ${ }^{18}$

La revolución política que se produjo en la Península entre 1810 y 1814 nos remite a una sola ciudad, Cádiz; un hecho que, como trataré de mostrar enseguida, nos pone en la pista de por qué el pueblo español recibió a Fernando VII como lo hizo a su regreso a territorio español en la primavera de $1814 .{ }^{19}$ Este aspecto me da pie para poner de manifiesto otro contraste entre la revolución liberal española y el proceso emancipador novohispano. El hecho de que esa revolución haya tenido su epicentro en Cádiz, un puerto escasamente representativo del conjunto de España, contribuye a explicar tanto el radicalismo que en algunos aspectos manifestó la transformación política emanada de ahí, como su estrepitosa caída en la primavera de 1814. Una caída que, al parecer, la mayoría de los españoles contemplaron sin

18 Más adelante volveré al tema de los Guadalupes, pero me parece importante dejar claro desde ahora que las transformaciones en la mentalidad política novohispana, concretamente en algunos criollos que percibían la necesidad de cambios profundos en el virreinato, preceden cronológicamente a la insurgencia. Sobre el tema, el libro imprescindible es Guedea, En busca de un gobierno alterno.

${ }^{19} \mathrm{La}$ Historia del levantamiento, guerra y revolución de España del Conde de Toreno, publicada originalmente entre 1835 y 1837, sigue siendo quizá el mejor relato, amén del más completo, sobre este periodo de la historia española (aunque, es cierto, demasiado centrado en la historia puramente militar). Existe una edición reciente (Pamplona: Urgoiti Editores, 2008), con un magnífico estudio preliminar de Richard Hocquellet. Sobre el apoteósico regreso de "El Deseado" a territorio español, véanse las pp. 1179-1182. Sobre este libro, sobre Toreno y sobre su falta de perspicacia respecto al "problema americano", escribí una extensa reseña, que puede resultar de interés para algunos lectores: "La Historia de Toreno y la historia para Toreno". 
mayores resquemores. Dicho en otras palabras, el control que sobre la situación política gaditana lograron los liberales desde muy temprano se convirtió en humo una vez que el invasor se retiró del territorio español.

Ahora bien, la manera en que Fernando VII fue recibido en cada pueblo, villa y ciudad por las que pasaba camino a Madrid, a su regreso del cautiverio en Francia, no sólo se explica por un mayor o menor desencanto del pueblo con los liberales y su programa. Pesó también, y seguramente en mayor medida, el cansancio que agobiaba a los españoles después de una larga contienda de enorme virulencia. ${ }^{20}$ Asimismo, también pesó en el ya mencionado regreso triunfal del rey el hecho de que él representaba muchos de los motivos que estaban detrás de los incontables sacrificios que había hecho el pueblo español durante seis años; a este respecto, el sobrenombre de "El Deseado", con que se conoció al monarca casi desde el inicio de su cautiverio, es elocuente. Unos sacrificios que, por lo demás, reflejan el tradicionalismo sociorreligioso que caracterizó a la lucha popular contra el invasor galo, considerado por la mayoría de los españoles como impío en lo religioso y como revolucionario y regicida en lo político. En suma, volviendo a Cádiz, se puede decir que la ciudad fue un reducto extraordinario

${ }^{20}$ Otra vez fue Goya quien mejor retrató el salvajismo que alcanzó la llamada por los españoles "Guerra de la independencia" (denominada Guerra del francés por los catalanes y Peninsular War por los ingleses). Esta vez, en la serie de grabados que el propia Goya tituló Fatales consecuencias de la sangrienta guerra en España con Bonaparte, pero que se conoce como Los desastres de la guerra. Estos grabados se han convertido en un símbolo artístico de la crueldad, el sinsentido y el nivel de deshumanización que conlleva todo conflicto bélico, en cualquier lugar y época. 
en medio de una situación extraordinaria. Sin duda, este hecho fue muy bien aprovechado por los liberales peninsulares (políticos, publicistas, periodistas y agitadores), cuya habilidad política es incuestionable, pero también tuvo consecuencias que resultaron decisivas para el futuro del liberalismo en España desde el momento en que la situación en la Península comenzó a normalizarse. ${ }^{21}$

En la Nueva España, los insurgentes lograron tener el control de varias ciudades importantes durante los primeros años de su movimiento; sin embargo, hasta la fecha los historiadores mexicanos siguen discutiendo el mayor error estratégico cometido por Hidalgo: su negativa a invadir la capital del virreinato a principios de noviembre de 1810, después de su victoria en el Monte de las Cruces. ${ }^{22}$ Sin el

${ }^{21}$ Uno de los ámbitos en los que los liberales lograron "imponer condiciones" fue el de la prensa. Esto no significa, por lo demás, que las expresiones anticonstitucionales no hayan sido numerosas ni tampoco que hayan sido impedidas de expresarse libremente, primero al amparo del Decreto de libertad de imprenta de noviembre de 1810 y luego del artículo 371 de la Constitución; sin embargo, el predominio liberal en el ámbito impreso gaditano, tanto en términos cuantitativos como cualitativos, está fuera de duda. Sobre el tema, crucial para entender la también llamada "revolución doceañista", véanse los tres volúmenes de Durán López, Cantos Casenave y Romero Ferrer (eds.), La guerra de pluma, así como Durán López y Larriba, El nacimiento de la libertad de imprenta. ${ }^{22}$ Para Herrejón, son cuatro las razones puntuales de esta decisión: la falta de adhesión dentro de la ciudad, la mortandad que había causado la artillería realista en el Monte de las Cruces, el avance de los ejércitos virreinales hacia la capital y la carencia de municiones HerReJón, Hidalgo, p. 388. Por cierto, aunque Morelos nunca tuvo una oportunidad similar a la de Hidalgo respecto a la capital, aparentemente pudo haberse apoderado de Puebla en noviembre de 1811 (e incluso todavía en 1812). La caída de Puebla hubiera significado para Morelos disponer de una "cabeza de playa" con miras a la ciudad de México, aunque hubiera 
control de la ciudad de México, era imposible terminar con el poder peninsular, independientemente del tipo de gobierno que Hidalgo pensara instaurar. En cualquier caso, tanto Hidalgo como Morelos, a pesar de todas sus diferencias en cuanto a la manera de alcanzar sus objetivos, terminarían siendo derrotados por las autoridades constituidas. Como quedó dicho, lo mismo sucedió con los liberales de la Península. En ambos casos, la derrota se debió al mayor poderío de los adversarios; principalmente militar en el caso novohispano, sobre todo político en el peninsular (aunque el apoyo casi unánime de los altos mandos a Fernando VII a su regreso de territorio francés fue determinante).

En la Nueva España, a partir de finales de 1813 la superioridad militar de las autoridades virreinales fue cada vez más clara; aunque, repito, no se puede decir que el movimiento insurgente en general haya sido "derrotado", pues nunca pudo ser controlado del todo. Este hecho, junto con una supuesta continuidad que a menudo se establece entre la primera insurgencia (la de Hidalgo y Morelos) y la obtención de la independencia bajo la égida de Iturbide en 1821, ha contribuido a presentar el proceso emancipador novohispano en su conjunto bajo una luz que tiende a pasar de largo sobre las enormes diferencias entre el proyecto político social de Hidalgo o Morelos y el de Iturbide. Más aún respecto al segundo de los dos líderes insurgentes, pues por razones en las que no viene a cuento detenerse y poniendo entre paréntesis las diferentes circunstancias bajo las que se

implicado también una enorme "inversión" de hombres, amén de sacrificar parcialmente su movilidad, que siempre fue uno de los grandes aciertos de la estrategia militar de Morelos. 
desempeñaron, las inquietudes propiamente políticas son mucho más evidentes en Morelos que en su predecesor. En cualquier caso, de lo anterior se desprende la inadecuación del término "consumación", aludida más arriba, para referirse a lo sucedido en la Nueva España en $1821 .^{23}$

En el caso peninsular, el motivo principal del fracaso del liberalismo fue la superioridad que supuso para Fernando VII una vuelta a territorio español bajo una serie de condiciones que, como he señalado, le favorecieron naturalmente. A esto hay que añadir las muestras de apoyo decidido por parte de los 69 diputados firmantes del documento conocido como "Manifiesto de los persas", dado a conocer en abril de 1814, en que se descalificaba toda la labor política de las Cortes, legitimando así en cierta medida una vuelta al absolutismo. Más importantes, sin embargo, fueron otros elementos. El primero fue el ya mencionado apoyo incondicional a la majestad real por parte de los altos mandos militares, pero cabe también señalar otros dos. El primero es el

${ }^{23}$ Ateniéndonos a la definición del DRAE, ¿en qué sentido se puede decir que Iturbide "llevó a cabo totalmente" el proceso iniciado por Hidalgo? No es éste el lugar para intentar dilucidar una cuestión tan compleja, pero no está de más apuntar que, más allá de no haber buscado la independencia absoluta de manera inequívoca, en varios aspectos y momentos Hidalgo se alejó de la figura de Fernando VII; un alejamiento que se convirtió en ruptura en el caso de Morelos. Se puede decir que Iturbide, por su parte, fue fiel al monarca español hasta el final del proceso emancipador, al grado de ofrecerle la corona de México, obteniendo así la "independencia absoluta" al amparo de quien hasta ese momento había sido el rey metropolitano y, en más de un sentido, el principal enemigo de la independencia de México. En cuanto a la distancia entre el proyecto sociopolítico que tenía en mente Morelos y el de Iturbide, creo que el contraste podría empezar por comparar los 23 Sentimientos de la Nación con los 23 puntos del Plan de Iguala. 
hecho de que buena parte de las guerrillas estaban en territorio francés persiguiendo al enemigo en fuga y el segundo son las escasas ventajas concretas que el pueblo español pudo haber percibido o recibido de las disposiciones liberales.

Todo lo anterior, aunado a la "guerra” que la jerarquía católica peninsular había declarado a los liberales en todos los frentes, explica la suerte que corrió el liberalismo gaditano a partir del regreso del monarca al territorio español. Revelador de esta suerte, así como de la ingenuidad de Fernando VII, es el real decreto de principios de mayo de 1814 (como se puede ver, el monarca se creía capaz de anonadar a la historia):

[...] declaro que mi real ánimo es, no solamente no jurar, ni acceder a dicha Constitución, ni a decreto alguno de las Cortes Generales y Extraordinarias, y de las Ordinarias actualmente abiertas, a saber: los que sean depresivos de los derechos y prerrogativas de mi soberanía establecidas por la Constitución y las leyes, en que de largo tiempo la Nación ha vivido, sino el declarar aquella Constitución y decretos nulos y de ningún valor ni efecto, ahora ni en tiempo alguno, como si no hubiesen pasado jamás tales actos, y se quitasen de en medio del tiempo, y sin obligación en mis pueblos y súbditos, de cualquiera clase y condición, a cumplirlos y guardarlos. ${ }^{24}$

La victoria absolutista fue una victoria sin paliativos, que desencadenó una feroz represión contra los liberales. Poniendo entre paréntesis el Trienio Liberal, no sería sino hasta que la muerte de Fernando VII, acaecida en 1833, coincidiera con una delicada cuestión sucesoria, que el

${ }^{24}$ Cito de la Historia de Toreno, p. 1181 n. 406. 
liberalismo español iniciaría su singladura decimonónica en condiciones de una cierta normalidad. Relativa, sin duda, pues la primera guerra carlista ya tenía tres años de iniciada cuando la Constitución de 1812 revivió fugazmente entre 1836 y 1837, antes de que fuera sustituida de forma definitiva por otro texto constitucional (exactamente un cuarto de siglo después de haber sido promulgada en Cádiz). A partir de ese momento, el liberalismo español se alejaría cada vez más de algunos de los postulados radicales de la Constitución gaditana. ${ }^{25}$

Antes de seguir, conviene desarrollar algunos aspectos de los dos procesos aquí estudiados, sobre todo porque si bien desde diversas perspectivas se pueden considerar opuestos, no lo fueron en un primer momento y no lo serían durante mucho tiempo desde la perspectiva de muchos habitantes de la Nueva España. ${ }^{26}$ En la medida en que la revolución liberal española y el proceso emancipador novohispano son respuestas a la misma crisis, al principio de ésta la salida buscada va en el mismo sentido: guardar en depósito la soberanía de Fernando VII. En el caso peninsular, esta salida desembocó, después de la creación de numerosas juntas

${ }^{25}$ Para dar paso a un moderantismo que caracterizaría a la monarquía constitucional española durante el resto del siglo. Algunos autores dirán que dicho alejamiento se inició desde mucho antes; véase, por ejemplo, Morange, Una conspiración fallida. Sobre la moderación política del liberalismo español decimonónico vis-à-vis el liberalismo doceañista, véase Varela Suanzes, "La Constitución de Cádiz"; este artículo fue publicado originalmente en 1987.

${ }^{26}$ Pese a ser algo bien conocido por los historiadores, no está de más recordar aquí que el proceso emancipador novohispano, como los demás procesos independentistas hispanoamericanos, fue una guerra civil, no un enfrentamiento entre americanos y peninsulares. 
locales y de no pocas peripecias, en la Junta Central. En el caso novohispano, por su parte, el "golpe de Estado" de Yermo contra Iturrigaray instaló a otro virrey, el octogenario militar retirado Pedro de Garibay, quien estaba imposibilitado para lograr la legitimidad perdida a causa de la manera en que había llegado al poder. ${ }^{27}$

A partir de septiembre de 1810, con el levantamiento de Hidalgo en la Nueva España y con la reunión de las Cortes de Cádiz en el Viejo Mundo a partir de ese mismo mes, la relación entre los dos procesos que nos ocupan se torna muy compleja. Por un lado, Hidalgo, quien por cierto en algún momento consideró participar como representante de la Nueva España en dichas cortes, se convirtió en el principal enemigo de las autoridades virreinales y objeto de todas sus preocupaciones. ${ }^{28}$ Lo mismo sucedió con Morelos más adelante, pues la desastrosa derrota de Hidalgo en Puente de Calderón en enero de 1811 significó el final de su aventura insurreccional y de su liderazgo político. Hidalgo fue

${ }^{27}$ De hecho, Garibay fue pronto removido por la Junta Central; en total, permaneció sólo 10 meses en el cargo. El mismo tiempo, por cierto, que duraría como virrey su sucesor, el clérigo Francisco Javier Lizana y Beaumont. Esto significa que en un lapso de dos años, entre septiembre de 1808 y septiembre de 1810, fueron cuatro los virreyes que estuvieron al frente del territorio más importante del imperio español en América, además del gobierno provisional de la Audiencia de México entre mayo y septiembre de 1810 (en este último mes tomó posesión Francisco Javier Venegas). Creo que este dato, por sí solo, dice mucho sobre la magnitud de la crisis en la Nueva España.

${ }^{28}$ Sobre Hidalgo como posible diputado en Cádiz, Herrejón escribe: “Al cura no le desagradó la idea, pues finalmente veía una alternativa pacífica para el cambio donde él podría estar entre los protagonistas". HerreJón, Hidalgo, p. 276. A fin de cuentas, el ayuntamiento de San Miguel el Grande optaría por otros candidatos. 
apresado poco después de esa derrota y fusilado en julio de ese mismo año. Aunque la gesta hidalguense había durado apenas cuatro meses, la vorágine social a la que dio origen cambió para siempre la faz del virreinato y terminaría llevando, si bien por caminos insospechados, a la independencia.

Al igual que en el caso de Hidalgo, durante algún tiempo la postura de Morelos respecto a Fernando VII fue ambigua. Sin embargo, a partir de cierto momento el "Caudillo del Sur” se decantó por excluir al monarca, lo que provocó no pocos sinsabores a su relación con Ignacio López Rayón, un "fernandista" que, hasta ese momento, era el líder ideológico más importante de la insurgencia; no sólo por su papel en la creación de la Junta de Zitácuaro, sino también por ser el autor de los "Elementos constitucionales". ${ }^{29}$ Por su parte, en la capital del virreinato los Guadalupes mantuvieron una postura que puede considerarse ambivalente respecto a la monarquía en desgracia o, si se prefiere, de un enorme pragmatismo político. Aunque esta postura varía dependiendo del Guadalupe que tengamos en mente (no olvidemos que se trata de un grupo con más de 40 integrantes, entre ellos tres mujeres), en términos generales apoyaron a Morelos, lo que no implicaba necesariamente haber optado por una ruptura abierta con el rey, y menos aún con la monarquía.

Como adelanté, el periodo denominado la "consumación” de la independencia de México muestra hasta qué punto era posible seguir considerando a Fernando VII

${ }^{29}$ Me refiero sobre todo a la autoría material de los "Elementos", pues, como se puede inferir de la carta que Morelos le envió el 7 de noviembre de 1812, Rayón no fue el único autor intelectual del texto. De esa misiva se desprende que tanto Morelos como Hidalgo participaron de modo importante en su concepción. Véase Lemoine (ed.), Morelos, p. 227. 
la persona adecuada para dirigir los destinos de la Nueva España y, al mismo tiempo, apoyar lo que la historiografía actual denomina la "independencia absoluta". Sobre este tema, cabe debatir acerca de las intenciones de Iturbide cuando en el punto $4^{\circ}$ del Plan de Iguala propone a Fernando VII como emperador de México; sin embargo, se olvida en ocasiones que la propuesta en dicho punto va mucho más allá del rey de España en aquel momento, pues comprende también a algunos miembros de su dinastía e incluso a los de otra casa reinante. En todo caso, parece incuestionable que el contexto que llevó a Iturbide a planear la independencia resulta ininteligible sin conocer los acontecimientos peninsulares. ${ }^{30}$ Independientemente del debate sobre el carácter más o menos conservador de la "consumación" de la independencia de México, me parece que estos acontecimientos no se calibran lo suficiente al estudiar esta fase del proceso emancipador de la Nueva España. A este respecto, cabe apuntar que las reacciones de rechazo o desaprobación

30 Por "acontecimientos peninsulares" me refiero sobre todo al regreso del liberalismo en la Península en la primavera de 1820 y a la serie de medidas que las Cortes de Madrid empezaron a discutir desde mediados de ese año. Al respecto, en su escrito autobiográfico conocido como "Memoria de Liorna", Iturbide escribe: "Restablecióse el año de veinte la Constitución en las Españas. El nuevo orden de cosas, el estado de fermentación en que se hallaba, las maquinaciones de los descontentos, la falta de moderación en los amantes del nuevo sistema, la indecisión de las autoridades, y la conducta del gobierno de Madrid y de las cortes que parecían empeñadas en perder aquellas posesiones, según los decretos que expedían, según los discursos que por algunos diputados se pronunciaron, avivó en los buenos patriotas el deseo de independencia [...]" (p. 42, todas las cursivas son mías). Iturbide, Manifiesto al Mundo. Esta edición, integral y compulsada con ediciones anteriores, estuvo a cargo de Laura Suárez de la Torre, quien también es la autora del prólogo. 
ante una "consumación" de índole eminentemente conservadora son propias de la historiografía mexicana, no de la extranjera, que asume este aspecto de la parte final del proceso novohispano sin reparos (axiológicos, ideológicos o intelectuales). ${ }^{31}$

Lo que se consumó en septiembre de 1821 fue la separación definitiva entre dos procesos que empezaron como respuestas a una misma crisis política, que se alejaban o acercaban, dependiendo del momento político y del líder insurgente o del intelectual público novohispano que tengamos en mente, y que fue llevada a cabo por alguien que durante muchos años fue un acérrimo opositor de la insurgencia. Entre los intelectuales públicos aludidos, creo que el caso de Carlos María de Bustamante resulta ilustrativo. El consejero de Morelos, que tan importante papel desempañara en Apatzingán, es la misma persona que años más tarde, en 1820, redactó y publicó un texto denominado "Motivos de mi afecto a la Constitución”, que es un encendido elogio de la Constitución de Cádiz. ${ }^{32}$ Mutatis mutandis, lo mismo

31 Por mencionar un solo ejemplo, John Elliott resume así lo sucedido en la Nueva España entre 1820 y 1821: "Ante tales amenazas a sus derechos corporativos, es decir [los decretos que las Cortes de Madrid estaban preparando o aprobando para reducir ciertos privilegios militares y eclesiásticos], los criollos y peninsulares de la Nueva España dejaron a un lado sus diferencias y se unieron en una frágil coalición para hacer causa común contra los designios de los liberales peninsulares [...]”. Y concluye al respecto: "Se trataría, pues, de una contrarrevolución concebida para defender un orden establecido, eclesiástico y estatal, que ya no garantizaba su protector tradicional, la monarquía española”. Elliot, Imperios del mundo atlántico, p. 567.

32 El texto constituye el séptimo de los diez "juguetillos" que Bustamante escribió entre 1812 y 1821 . Remito a la edición integral y facsimilar del Centro de Estudios de Historia de México titulada Juguetillo; la 
se podría decir de otros destacados hombres públicos novohispanos, como el cura Francisco Severo Maldonado y, de manera menos evidente quizá, el periodista Joaquín Fernández de Lizardi, cuyas oscilaciones políticas han sido puestas casi siempre entre paréntesis por la historiografía mexicana que se ha ocupado en años recientes de la vida y obra de "El Pensador Mexicano". ${ }^{33}$ Entre quienes combinaron la pluma con la vida política, José María Cos me parece un excelente ejemplo de las oscilaciones mencionadas. ${ }^{34}$ Como se puede ver considerando los nombres que aparecen en este párrafo, estamos ante personajes de primera línea del proceso emancipador novohispanomexicano.

paginación, 1-43, es la de la edición original de la imprenta de D. Alejandro Valdés, 1820. Este "juguetillo" (dedicado, por cierto, a "El Pensador Mexicano") va precedido de un epígrafe de Filangieri: "No basta persuadir al pueblo [de] la debilidad de la antigua legislación: debe prevenírsele en favor de la nueva, valiéndose para ello de argumentos sensibles que nazcan del concepto mismo que suele formar el pueblo de las cosas".

${ }^{33} \mathrm{La}$ actitud escasamente crítica de algunos académicos mexicanos ante las zigzagueantes simpatías político sociales de Lizardi queda de manifiesto en el estudio preliminar que escribió María Rosa Palazón Mayoral para la Antología general que coeditaron el FCE, la FLM y la UNAM en 2006; dicho estudio se titula "Una bella persona utópica" (pp. 15-49).

${ }^{34}$ Más allá del empleo del término "claudicaciones" por parte de Ernesto Lemoine para referirse a la vida de Cos y de que una supuesta "tarea del historiador" es explicarlas, el estudio preliminar que este reconocido historiador escribió para una antología política de Cos, publicada hace casi medio siglo, muestra bien la magnitud de dichas oscilaciones. Cos, Escritos políticos; los entrecomillados son de la p. lxii. Por lo demás, los textos de esta antología corroboran las incertidumbres y vaivenes del doctor Cos, cuyo "sino y drama", en palabras de Lemoine, "fue albergar en su cuerpo y en su alma a dos individuos a la vez, indisolubles e inseparables, en pugna el uno contra el otro" (p. lxx). 
Es en buena medida por razones que se infieren de los párrafos anteriores que planteamientos dicotómicos como el que hace Jaime Rodríguez en la última interpretación general de la independencia novohispana no pueden dar cuenta, desde mi punto de vista, de lo acontecido política, ideológica e intelectualmente en el virreinato entre 1808 y $1821 .{ }^{35}$ En el caso específico de dicho autor, se trata de una independencia concebida básicamente como la confrontación entre la revolución política gaditana y la insurgencia novohispana (siempre en detrimento de la segunda).

Ante una crisis de la magnitud de la que vivió el mundo hispánico a partir de 1808, en la que los principales referentes políticos desaparecieron o se desplazaron notablemente, conviene hacer un esfuerzo por situarse en ese mundo para tener una idea, lo aproximada que se quiera, del nivel de incertidumbre e indeterminación que afectó a todos los actores. Por el contrario, con lo que nos topamos a menudo es con un afán de otorgarle a esta situación de profunda desazón una supuesta "inteligibilidad histórica" que lo que hace es obviar la incertidumbre y que, en esa medida, tiende a minimizar, tergiversar o justificar vacilaciones que, desde mi punto de vista, debieran aceptarse como tales. En el caso del proceso emancipador novohispano, no hacerlo facilita el camino hacia idealizaciones de la insurgencia que, desde mi punto de vista, poco pueden contribuir a sacar a la luz las indeterminaciones ideológicas, así como los recovecos

\footnotetext{
35 Me refiero a su libro "We are now the true spaniards", citado en la nota 5 (en donde también se puede ver la referencia de la edición en español). Expuse brevemente los motivos centrales de lo que considero las insuficiencias interpretativas de este libro en la reseña que escribí para la Hispanic American Historical Review, 95: 1 (feb. 2015), pp. 157-159.
} 
políticos y doctrinales que la recorren de parte a parte. Lo mismo se puede decir, por supuesto, sobre el proceso gaditano (tema al que volveré al final de este artículo). Al respecto, el ensalzamiento de este proceso por parte de autores como Rodríguez en el libro referido o de historiadores españoles como Manuel Chust, que ha escrito un sinnúmero de trabajos sobre el tema, difícilmente puede contribuir a desentrañar la complejidad política, ideológica y doctrinal que caracteriza al mundo hispánico del primer cuarto del siglo XIX. ${ }^{36}$

En cuanto a la historiografía actual sobre la insurgencia, tengo en mente textos como "Independencia sin insurgentes. El bicentenario y la historiografía de nuestros días”, de Luis Fernando Granados, y, más recientemente, el artículo "El liberalismo en la insurgencia novohispana: de la monarquía constitucional a la república, 1810-1814”, de Cristina Gómez Álvarez. ${ }^{37}$ En otro lugar he expresado mis profundos desacuerdos con los presupuestos, el contenido y las conclusiones del texto de Granados, por lo que aquí me referiré brevemente a este artículo. ${ }^{38}$ En cambio, comentaré ciertos aspectos del texto de Gómez Álvarez que me

${ }^{36}$ En el caso de Chust, por un lado tiende a mitificar al liberalismo hispánico, y, por otro, a tergiversar y desacreditar la obra de Guerra. Como ejemplo de lo primero, véase CHust, "Guerra, revolución y liberalismo en México 1808-1835”, específicamente pp. 157 y 158. Como ejemplo de lo segundo, véase su artículo "Nueva España versus México", en especial, pp. 24 y 25. Ambos artículos fueron escritos por Chust en colaboración con José Antonio Serrano.

37 El primero apareció en Desacatos, 34 (sep.-dic. 2010), pp. 11-26; el segundo en Secuencia, 89 (mayo-ago. 2014), pp. 9-26.

${ }^{38}$ Los desacuerdos aludidos los expuse en "Límites del liberalismo y del constitucionalismo hispánicos”, pp. 47-66. 
parecen relevantes respecto a algunos de los temas centrales del presente ensayo.

El artículo de Gómez Álvarez, como el de Granados, surge de un evidente malestar: el que provoca a sus autores la percepción de que en la conmemoración bicentenaria de la independencia de México hubo un gran ausente: el estudio de la revolución insurgente. El principal motivo de esta ausencia Gómez Álvarez lo encuentra en el hecho de que en la historiografía actual sobre la independencia predomina una interpretación que afirma que el liberalismo gaditano fue "el que constituyó la verdadera revolución y [el] que provocó las transformaciones políticas que dieron lugar a la independencia y a la construcción del Estado y de la nación mexicanos" ${ }^{39}$ No obstante, el único ejemplo que la autora proporciona como representante de esta historiografía en la segunda nota de su artículo es el de Jaime Rodríguez.

No es ninguna casualidad que a pesar de que la autora afirma que lo que ha predominado en los últimos años es la historiografía "llamada revisionista" (p. 9), la lista de historiadores revisionistas se reduzca a un solo nombre de forma explícita. ${ }^{40} \mathrm{Y}$ no lo es porque Rodríguez es prácticamente el único historiador que, hasta donde alcanzo a ver, no sólo considera al liberalismo gaditano como la única revolución realmente importante durante el proceso emancipador novohispano, sino que además tiende de manera casi

39 Gómez Álvarez, "El liberalismo en la insurgencia novohispana”, p. 9. Para hacer la lectura más fluida, en lo que sigue todas las referencias tomadas del escrito de Gómez Álvarez las pondré entre paréntesis dentro del texto.

${ }^{40}$ El otro nombre que aparece ligado a esta corriente, en la nota 3 del artículo que ahora nos ocupa, es el ya mencionado Manuel Chust. 
obsesiva a minimizar los logros y la trascendencia de la revolución insurgente. Ahora bien, si la historiografía "revisionista" es tan predominante como Gómez Álvarez plantea en la primera parte de su artículo, cabía esperar que proporcionara una serie de nombres de los autores que la integran. En cualquier caso, paso ahora a cuestiones de contenido de los dos artículos mencionados.

En su texto, Gómez Álvarez sigue algunos de los planteamientos centrales del que parece considerar el único balance historiográfico que se ha escrito hasta la fecha sobre las conmemoraciones bicentenarias: el texto de Granados arriba mencionado. En este artículo, el autor ignora las marcadas diferencias que existen entre estudiosos del tema como François-Xavier Guerra, Antonio Annino, Jaime Rodríguez, Peter Guardino, Jaime del Arenal, Elías Palti, Juan Ortiz Escamilla, José Antonio Serrano, Alfredo Ávila, Rafael Rojas, José María Portillo Valdés y quien esto escribe. En opinión de Granados, "la orientación de la nueva historiografía sobre las primeras décadas del siglo xIx parece sugerir que por fin ha llegado el momento de remover a la insurgencia de la memoria colectiva [de los mexicanos] y emplear otras metáforas y otras imágenes para representar la Independencia nacional". ${ }^{41}$ Para Granados, como resulta evidente en la parte final de su artículo, el pecado historiográfico cometido por todos los autores mencionados es haberse olvidado "de esos miles de insurgentes de a pie, humildes, insignificantes", que con sus actos "hicieron mucho más por redefinir el paisaje social y cultural de Nueva España que los letrados de toda índole con sus proyectos

${ }^{41}$ Granados, “Independencia sin insurgentes”, p. 20. 
constitucionales, sus referencias librescas, su sabiduría cosmopolita”. La conclusión del autor es que lo mejor, es decir, lo “más sano y más productivo” (en lugar de deplorar el curso que han tomado los estudios sobre la independencia), es aprovechar el bicentenario "para ocuparnos de las insurrecciones hidalgueñas”. Su propuesta final es que la sociedad mexicana debe servirse de las celebraciones del 2010 “para pensar una vez más si el propósito de la vida social es dejar que cada cual se rasque con su propias uñas, o si mejor hacemos algo - lo que sea, pero ideológicamente encarnado como hicieron los insurgentes - antes de que el país termine de desmoronarse". ${ }^{42}$

En cuanto al artículo de Gómez Álvarez, me parece discutible su punto de partida: "la consideración de que la lucha armada iniciada el 16 de septiembre de 1810 tenía como propósito la independencia” (p. 10; es decir, para la autora, la independencia absoluta). Como quedó apuntado, si Hidalgo buscó desde el primer momento la independencia absoluta es una discusión que sigue abierta; en esa medida,

42 Todos los últimos entrecomillados en Granados, "Independencia sin insurgentes”, p. 24. Un presupuesto que está presente tanto en la obra de Rodríguez como en los artículos de Granados y Gómez Álvarez, es la noción de que la revolución gaditana y el movimiento insurgente son procesos que responden a una lógica de suma cero (esto es, todo lo que una gana, el otro lo pierde). Desde mi punto de vista, como he pretendido mostrar en el presente artículo, las cosas fueron bastante más complejas. En relación con esta cuestión, no está de más señalar que las interpretaciones de la independencia de México centradas en los insurgentes fueron las predominantes hasta, digamos, finales de la década de 1980, es decir, durante casi 170 años. Esto significa que las interpretaciones que enfatizan o subrayan la importancia del papel desempeñado por el proceso gaditano tienen un cuarto de siglo de haber comenzado a difundirse y debatirse (en el medio académico). 
plantear dicho propósito como punto de arranque resulta controvertible. Difiero también con otro aspecto del análisis que hace Gómez Álvarez y que en parte se deriva del anterior; me refiero a su manera de entender la Constitución de Apatzingán. En primer lugar, no creo que dicho documento sea el "resultado de varios años en que se fue reconstruyendo y afinando un proyecto que le diera estatuto político y jurídico al Estado independiente" (p. 12). Esta manera de ver al Decreto constitucional para la libertad de la América mexicana es un buen ejemplo de lo que yo llamaría "historia retrospectiva”. Este modo de enfocar el proceso emancipador novohispano no sólo no termina de marcar una verdadera distancia respecto a la historiografía nacionalista más tradicional, sino que minimiza o desvirtúa las dudas y vacilaciones que, de distintas maneras, tanto Hidalgo como Rayón y Morelos manifestaron respecto al camino político a seguir (por no mencionar a otros líderes insurgentes de segundo nivel).

Por otro lado, en ocasiones la autora extrae conclusiones controvertibles de ciertos pasajes de textos de la época. Pienso, por ejemplo, en las palabras siguientes de Hidalgo: "Establezcamos un Congreso que se componga de representantes de todas las ciudades, villas y lugares de este reino, que teniendo el objetivo principal de mantener nuestra santa religión, dicte leyes suaves, benéficas y acomodadas a las circunstancias de cada pueblo" (p. 15). No creo que de estas palabras, extraídas del célebre manifiesto de mediados de noviembre de 1810 que Hidalgo dio a conocer como respuesta a ciertos cargos que le hizo la Inquisición, se pueda decir lo siguiente: "No cabe duda de que estas palabras tienen una gran 
influencia del pensamiento ilustrado y liberal" (p. 15). ${ }^{43}$ Por otra parte, las indeterminaciones de la insurgencia novohispana difícilmente se resuelven con la hipótesis de Gómez Álvarez en el sentido de que el carácter revolucionario de la misma se mantiene incólume porque la inclusión del rey dentro de su propuesta política "se debe a que se está concibiendo una monarquía constitucional como forma de organización del nuevo Estado" (p. 16; volveré a esta cuestión un poco más adelante). Intentar establecer una continuidad entre Hidalgo, Rayón y Morelos con base en la idea de una monarquía constitucional no resiste un análisis cuidadoso, aunque sólo sea porque, utilizando una expresión de la propia autora, a fines de 1812 Morelos se "salía del guión de 1810" (p. 22) con su propuesta de excluir a Fernando VII de la Constitución que tenía en mente. Esta postura del

${ }_{43}$ De hecho, llama la atención que a estas alturas historiográficas se sigan haciendo afirmaciones como ésta. Como Carlos Herrejón lo ha planteado desde hace muchos años y como José Antonio Serrano lo afirma categóricamente en la revisión que hizo hace relativamente poco de la historiografía independentista: "El cura de Dolores no fue un revolucionario ilustrado". SERrano, "Deshaciendo el consenso", p. 140. Respecto a la recuperación que autores como Granados y Gómez quieren hacer del pueblo como un ente aparentemente monolítico, y respecto a su papel en la lucha independentista (también aparentemente monolítico), en este mismo artículo Serrano muestra la manera en que otra base sólida del consenso historiográfico que prevaleció durante muchísimo tiempo, el concepto de "pueblo insurgente", fue puesto en entredicho desde mediados de la década de 1980 por autores como Brian Hamnett, John Tutino, Christon Archer y Eric van Young (véanse pp. 141-143). Este artículo de Serrano es una revisión historiográfica muy útil; difiero, sin embargo, con la práctica equiparación que hace en su parte final en cuanto al influjo de Guerra y de Rodríguez sobre la historiografía contemporánea que se ocupa de las independencias hispanoamericanas. 
"Caudillo del Sur" no haría sino fortalecerse a lo largo de $1813 .{ }^{44}$

En cuanto a la supuesta claridad de Hidalgo sobre los objetivos políticos de la insurrección que desató en septiembre de 1810, que Gómez Álvarez plantea en su artículo (pp. 13-15), tiendo a estar de acuerdo con historiadores actuales como Jaime Olveda o, mucho más atrás, Hugh Hamill, quien hace medio siglo escribió: "La confusión de los motivos y de los objetivos declarados tres meses después de que la revuelta había empezado fue muy desafortunada [...] Hidalgo solamente introdujo vagos conceptos [al respecto] [...] Sus ideas del tipo de gobierno que debería suceder el logro de la libertad fueron indefinidas y su indecisión se revela en la vaguedad de sus declaraciones". ${ }^{45}$

${ }^{44}$ En cuanto al antimonarquismo de Morelos, en una carta de marzo de 1813, el "Caudillo del Sur" le dice a Rayón que está dispuesto a sacrificarse por la Junta (de Zitácuaro), pero por ningún motivo lo haría por alguno de sus miembros considerado individualmente. Enseguida, añade: "Y por lo mismo, jamás admitiré el tirano gobierno, esto es el monárquico, aunque se me eligiera a mí mismo por primero". Lemoine, Morelos, p. 279. Cabe apuntar que el personalismo de Rayón lo alejó no solo de Morelos, sino de varios miembros de la Junta. Por otra parte, el carácter republicano del Decreto no es explícito, pero se deriva, como lo señala Gómez Álvarez, del hecho de que el poder ejecutivo, denominado "Supremo Gobierno", consta de tres individuos que son elegidos por el poder legislativo (art. 103) y de la manera en que funciona dicho poder ejecutivo, esto es, mediante una presidencia cuatrimestral rotativa (art. 132). ${ }^{45}$ Hamill, The Hidalgo Revolt, p. 192 (traducción RB). Véase también Olveda, De la insurrección a la independencia. Por su parte, en Raíces de la insurgencia en México, HaMnetT afirma que el movimiento de Hidalgo "no había tenido una clara ideología ni fines políticos precisos". El subtítulo de este libro es Historia regional, 1750-1824 y la cita es de la p. 250. La edición de 2010 contiene un prefacio (pp. 9-16) en el que Hamnett hace una revisión de la bibliografía más importante publicada durante el cuarto 
Por otro lado, respecto al argumento de que el pensamiento político de Hidalgo refleja una clara influencia ilustra$\mathrm{da}$, cabe señalar que entre los autores favoritos del cura de Dolores se contaba el prelado Jacques-Bénigne Bossuet, a quien se puede considerar el más grande defensor del absolutismo. Sin embargo, el autor que al parecer Hidalgo leyó más que ningún otro fue Jacques-Hyacinthe Serry, un teólogo que de enciclopedista no tenía prácticamente nada. ${ }^{46}$ En relación con este tema, cabe decir que como la historiografía occidental ha mostrado desde hace tiempo, la Ilustración tenía vertientes que difícilmente pueden considerarse "modernas", menos aún "revolucionarias". Para terminar con esta cuestión, cabe concluir que la afirmación de que Hidalgo era "ilustrado" (expresada así, sin mayores aclaraciones o matices) dice bastante menos de lo que varios historiadores mexicanos han pretendido cuando emplean dicho vocablo. ${ }^{47}$

de siglo transcurrido entre 1986 y 2010. En dicho prefacio, el historiador británico expresa algunas reservas frente a la historiografía que recupera y enfatiza el papel del constitucionalismo gaditano para explicar el proceso emancipador novohispano (Guerra, Rodríguez y Annino); esto, conviene especificar, en la medida en que la obra de estos autores implica una marginalización de la insurgencia. Enseguida, como reacción a dicha historiografía, Hamnett recupera la importancia de historiadores como Tutino, Ortiz Escamilla y Van Young (véanse concretamente pp. 10-13).

46 Sobre las lecturas preferidas de Hidalgo, véase la biografía de Carlos Herrejón ya citada (nota 9), concretamente la primera parte del capítulo VII. Sobre Serry y su lejanía respecto al enciclopedismo, Herrejón es muy claro (ver la p. 263).

47 Lo cual no implica que Hidalgo no leyera a algunos autores ilustrados con connotaciones políticas claramente modernas (Genovesi, por ejemplo). A menudo, afirmaciones sobre el carácter ilustrado de tal o cual autor llevan implícita una vinculación supuestamente muy estrecha entre 
En lo que respecta al liberalismo del "padre de la patria", es cierto que en el pasaje citado más atrás Hidalgo planteó establecer un congreso con representantes de las ciudades, villas y lugares de la Nueva España, pero considerar que este planteamiento basta para hacer de Hidalgo un liberal es un salto que pocos estarían dispuestos a dar. De hecho, Hidalgo expresa enseguida que el objeto principal de dicho congreso era "mantener nuestra Santa Religión". ${ }^{48}$ Como ya señalé, el pensamiento de Hidalgo está atravesado por un tradicionalismo que se derivaba en gran medida de su condición de cura (de un pueblo, conviene tenerlo en mente, de una provincia de uno de los territorios americanos que más tiempo tardó en volverse independiente). Este tradicionalismo se refleja en incontables documentos, que retratan desde diversas perspectivas la manera en que Hidalgo entendía la lucha contra las autoridades virreinales (básicamente, como una contienda de carácter religioso). Que el tradicionalismo insurgente podía combinarse con nociones liberales es, como ya señalé también, innegable en el caso de Morelos, pero esto resulta menos claro en el caso de Hidalgo. En

Ilustración y liberalismo. Esta vinculación es discutible en términos generales, pero creo que desde una perspectiva política lo es aún más respecto al mundo hispánico. Me ocupé de esta cuestión en los capítulos IV y $\mathrm{V}$ de mi libro El primer liberalismo español y los procesos de emancipación de América, 1808-1824, pp. 175-189 y 253-281. En todo caso, la discusión sobre dicha vinculación sigue abierta, pues también es cierto que en algunos aspectos es posible establecer líneas de continuidad. Sobre este tema, véase el sugerente texto de PAQuetTE "Introduction".

${ }^{48}$ Las mayúsculas no aparecen en el pasaje que cita Gómez Álvarez en su artículo, pero sí en muchas otras versiones del manifiesto que estamos comentando; véase, por ejemplo, el tomo II de la historia documental de J. E. Hernández y Dávalos, Historia de la guerra de Independencia de México, p. 303. 
suma, así como quedarnos con un Hidalgo puramente tradicional no nos lleva muy lejos (entre otros motivos porque una lucha emprendida en clave religiosa puede ser revolucionaria o tener consecuencias revolucionarias), quedarnos con un Hidalgo liberal tampoco nos permite avanzar mucho. ${ }^{49}$

Antes de terminar con el tema de los líderes insurgentes, conviene decir algo sobre la "monarquía constitucional” como la fórmula que podría explicar los vaivenes de la insurgencia novohispana durante los primeros años del proceso emancipador respecto a la figura de Fernando VII. En primer lugar porque las ambigüedades y vacilaciones de dicha insurgencia no se explican, no se pueden explicar en mi opinión, mediante un solo concepto o una sola hipótesis. Como he sugerido, resulta más fructífero en términos historiográficos admitir dichas ambigüedades y vacilaciones como tales. Tanto Hidalgo como Rayón, Morelos y Cos dudaron acerca el camino político a seguir en medio de una situación que era incierta, compleja y particularmente violenta, además de confusa en términos políticos, ideológicos y hasta doctrinales. En segundo lugar, porque el documento

${ }_{49}$ Aunque, por razones evidentes, esta segunda opción puede resultar más atractiva para algunos historiadores mexicanos. En lo que respecta al liberalismo de Hidalgo (y de la insurgencia novohispana en general), basta comparar el ideario político que es posible reconstruir con base en algunas de sus proclamas con el ideario de algunos de los principales líderes de los procesos emancipadores sudamericanos para darnos cuenta de que en diversos aspectos el liberalismo novohispano era bastante más tradicional que el de sus homólogos del resto del subcontinente. Por mencionar un solo aspecto, la insurgencia novohispana (Rayón y Cos, entre otros) parece haber sido la única en toda la América española en pedir el restablecimiento de la Inquisición, que había sido abolida por las Cortes de Cádiz en febrero de 1813. 
legal más importante que produjo la insurgencia, el "Decreto de Apatzingán”, no plantea una monarquía constitucional, sino un régimen de tipo republicano.

En relación con este tema, cabe decir algo sobre la supuesta antinomia monarquía-república. Desde el último cuarto del siglo xviII existe en el mundo occidental un planteamiento denominado en ocasiones "la indiferencia de las formas de gobierno", según el cual lo fundamental para el correcto funcionamiento de un régimen político es un punto crucial: el respeto de ciertos derechos individuales. En consecuencia, la forma de gobierno se convierte en una cuestión secundaria. ${ }^{50} \mathrm{Si}$ esto es así, el carácter revolucionario de la insurgencia no estaría determinado porque sus líderes adoptaran o no la monarquía constitucional. Lo que puede resultar difícil de entender para nosotros es que Iturbide pretendiera obtener la independencia manteniendo a Fernando VII en el trono; una incompatibilidad que Morelos tuvo clara a partir de cierto momento. No obstante, más allá de nuestras limitaciones para entender cabalmente esta manera de concebir un "rompimiento" con la metrópoli, y sin entrar en elucubraciones sobre lo que tenía en mente Iturbide cuando inició el camino independentista que lo

50 Sobre este tema, véase el artículo de SÁnchez-Mejía, “Repúblicas monárquicas y monarquías republicanas”. No está de más recordar que la revolución liberal gaditana se llevó a cabo en defensa y al amparo de una monarquía constitucional. A este respecto, la ola republicana que recorrió la América española a partir de 1811 se puede considerar, entre otras cosas, una autoafirmación vis-à-vis la metrópoli. Una autoafirmación que, cabe plantear, no calibró todas las implicaciones de la adopción de un sistema de gobierno en el que los hispanoamericanos no tenían experiencia alguna y que resultaba muy exigente en términos cívicos, electorales y representativos; exigencias para las cuales, en buena lógica, estaban mal equipados. 
terminaría llevando al trono imperial, lo cierto es que fue al socaire de Fernando VII como (posible) emperador del nuevo país que México obtuvo su independencia.

En el resto de la América española, la adopción generalizada del régimen republicano hace olvidar con frecuencia no sólo la historia, la polisemia y la variedad connotativa de la palabra "república", sino también, como ha señalado el historiador francés Clément Thibaud, el hecho de que los actores políticos muchas veces la invocaban con sentidos distintos, incluso contradictorios. Además, como nos recuerda este autor en un texto relativamente reciente, el empleo del vocablo por parte de varios estados republicanos "no implicaba necesariamente el carácter antimonárquico de esos Estados". ${ }^{51}$ En relación con el tema del liberalismo, concretamente del liberalismo hispánico, cabe apuntar que esta diversidad semántica que tuvo el término "república" durante los primeros años de las revoluciones hispánicas es un elemento más para rechazar la supuesta contraposición que algunos autores establecen entre el liberalismo y el republicanismo durante el primer cuarto del siglo xix en el mundo hispánico. Una contraposición que puede explicarse hasta cierto punto en el contexto ideológico político del proceso de independencia de las Trece Colonias y sus prolegómenos (de aquí la importancia que tuvo este debate en el ámbito académico estadounidense hasta hace no mucho tiempo), pero que difícilmente se justifica en el caso de los procesos emancipadores hispanoamericanos. ${ }^{52}$

51 Thibaud, "Les trois républiques de la Terre Ferme", la cita es de la p. 246 (traducción RB).

${ }_{52}$ Me ocupé de esta cuestión en BREÑA "Liberalismo y republicanismo", pp. 33-51. 
Desde mi punto de vista, dichos procesos, así como lo acontecido en Cádiz entre 1810 y 1814, eran movimientos revolucionarios en términos políticos porque todos ellos adoptaron una serie de principios que en el contexto de aquel momento bistórico eran revolucionarios (resumiendo: la soberanía nacional, la igualdad política, las libertades individuales, la división de poderes y el sistema representativo). Aunque cierta historiografía latinoamericana puede hacernos pensar lo contrario, estos principios no eran privativos de las repúblicas, como la monarquía constitucional gaditana lo muestra palmariamente. Ahora bien, estos principios podían dar pie a propuestas político sociales peculiares a cada uno de los procesos emancipadores (que en buena medida se explican por la diversidad en la conformación de las sociedades hispanoamericanas), incluso dentro de un mismo proceso (vuelvo aquí a los contrastes entre el proyecto de Morelos y el de Iturbide). ${ }^{53}$

En las últimas páginas he planteado algunas reservas frente a lo que considero idealizaciones recientes de la insurgencia novohispana; sin embargo, exactamente lo mismo se puede decir respecto a una parte de la historiografía

53 Este último paréntesis nos llevaría muy lejos en lo relativo al carácter de "consumación" que supuestamente tuvo la independencia de México. Que el estudio de esta etapa sigue sin dilucidar cuestiones importantes lo muestra de un modo fehaciente el intercambio que tuvo lugar hace un par de años en el blog cultural de la revista Nexos sobre la insurgencia. En este intercambio participaron historiadores como Juan Ortiz Escamilla, Alfredo Ávila, Catherine Andrews, Rodrigo Moreno, Marco Antonio Landavazo y Jaime del Arenal. Sobre los puntos principales que surgieron y se discutieron en ese intercambio electrónico en lo que respecta a la consumación en particular, remito a la contribución de Moreno: http:// cultura.nexos.com.mx/?p=5241 
española que se ha ocupado de la revolución política que tuvo lugar en la Península entre 1808 y 1814. Basta pensar en la manera en que las Cortes y la Constitución de Cádiz fueron planteadas por algunos académicos españoles durante las conmemoraciones bicentenarias que tuvieron lugar hace relativamente poco. La incapacidad de los liberales peninsulares para darse cuenta de que la pacificación de América era una condición sine qua non para todo lo demás, su subordinación respecto a los dictados del gremio comercial gaditano y lo limitada que fue la oferta de las Cortes en aspectos políticos y económicos que para los americanos resultaban cruciales son algunos de los rasgos que la historiografía peninsular bicentenaria prefirió ignorar o, por lo menos, poner entre paréntesis (como siempre, hubo excepciones). Creo también que los planteamientos de algunos historiadores españoles que sugieren una influencia de la carta gaditana sobre todo el subcontinente americano a lo largo de todo el periodo emancipador, así como un carácter supuestamente único de dicha carta en el contexto hispánico, requiere de una serie de matices y precisiones. ${ }^{54}$

54 No obstante, hay un aspecto en el que dicho carácter me parece incontrovertible: en medio de la "explosión” constitucional que, efectivamente, tuvo lugar en la América hispana entre 1811 y 1816, la Constitución de Cádiz fue la única concebida para toda la Monarquía. Que el proyecto gaditano haya fracasado y que tuviera una serie de limitaciones desde la perspectiva americana no le resta nada a su enorme osadía política y a su valor en términos de historia constitucional y de historia de las ideas. Al respecto, se olvida a menudo que apenas cuatro años antes de promulgada la Constitución (en cuya discusión y elaboración, no se olvide, participaron alrededor de 60 americanos), la Monarquía española era un régimen absolutista que en términos prácticos consideraba a los territorios de América como "colonias" y que trataba a sus habitantes en consecuencia. En su carácter bihemisférico, en su reconocimiento de los indígenas 
En cuanto al influjo de la Constitución de Cádiz sobre los territorios americanos, es muy importante hacer distinciones, tanto cronológicas como geográficas; estas últimas deben empezar por distinguir en cuáles territorios fue aplicada la Constitución y en cuáles no. ${ }^{55}$ Ahora bien, estas distinciones no implican que el proceso político gaditano no haya desempeñado un influjo considerable en casi todo el subcontinente, como la historiografía reciente lo ha mostrado. ${ }^{56}$ Una vez más, conviene insistir en la cautela analítica que debe prevalecer siempre al acercarnos a la historia política e intelectual del mundo hispánico durante el primer cuarto del siglo XIX. Si es importante seguir reivindicando una actitud de este tipo no es sólo porque ciertas interpretaciones actuales persisten en ensalzar al proyecto gaditano o en idealizar a la insurgencia novohispana, sino también porque, desde una perspectiva historiográfica más amplia,

como ciudadanos y en su apertura en términos de participación electoral, la Constitución de Cádiz es, sin duda, un documento señero en la historia constitucional de Occidente.

${ }^{55}$ La carta gaditana fue aplicada en los virreinatos de Nueva España y el Perú (con diferencia, los dos más poblados), así como en la Capitanía General de Guatemala. Sin embargo, también habría que hacer distinciones dentro de algunas de las posesiones del imperio español en América, pues, por ejemplo, varias ciudades de la Capitanía General de Venezuela y del virreinato de Nueva Granada, así como la ciudad de Montevideo, siguieron, en principio, a la constitución gaditana.

${ }^{56}$ Por poner un solo ejemplo (de uno de los territorios americanos que se mantuvo más aislado, supuestamente, de la influencia peninsular): en un libro publicado no hace muchos años, una reconocida especialista en el proceso emancipador rioplatense, Marcela Ternavasio, afirmó lo siguiente sobre la etapa que va de 1810 a 1816: "[...] todo parece conducir a que la experiencia gaditana tuvo una fuerte presencia en el proceso revolucionario rioplatense”. Ternavasio, Gobernar la revolución, p. 261, n. 198. 
la recuperación que desde hace algunos años está haciendo la academia anglosajona de las revoluciones hispánicas desde la perspectiva de la historia atlántica tiende también a simplificarlas. Esto se explica, de entrada, por una cuestión metodológica que, justamente por serlo, a veces pasa desapercibida: la interpretación atlántica de la llamada "Era de las revoluciones" privilegia las similitudes, las continuidades y los paralelismos.

No es éste el lugar para analizar el modo en que el enfoque atlántico tiende a minimizar o al menos a poner entre paréntesis la complejidad política, ideológica y doctrinal de las revoluciones hispánicas. ${ }^{57}$ Sin embargo, me parece que el tema es importante. No sólo por las consecuencias que dicho enfoque podría tener si sigue siendo aceptado por la historiografía latinoamericana de manera poco crítica, sino sobre todo por motivos que intenté poner de manifiesto en el presente ensayo historiográfico: dejar de sacar a la luz dicha complejidad nos llevaría, nolens volens, a una era de las revoluciones menos incierta, menos rica y menos diversa de lo que fue en realidad esta etapa de la historia política de Occidente.

${ }^{57}$ Me ocupé del enfoque atlántico en el capítulo 7 de mi libro El imperio de las circunstancias. Asimismo, analicé algunas de las implicaciones de las revoluciones hispánicas para la llamada "era de las revoluciones" en mi artículo "The Cadiz Liberal Revolution (1810-14) and Spanish American Independence" [en prensa]. Sobre la inserción de la revoluciones hispanoamericanas en la era de las revoluciones y sobre las diversas dificultades históricas e historiográficas que esto implica, véase la conclusión que Eric van Young escribió hace ya tres lustros para el libro editado por URIBE-URán, State and Society in Spanish America during the Age of Revolution, pp. 219-246); esta conclusión lleva por título "Was there an Age of Revolution in Spanish America?”. 


\section{REFERENCIAS}

Annino, Antonio y Raymond Buve (coords.)

El liberalismo en México, Münster, Asociación de Historiadores Latinoamericanistas Europeos, 1993.

ArCher, Christon

“'La Causa Buena': the Counterinsurgency Army of New Spain and the Ten Years' War”, en Rodríguez O. (ed.), 1989, pp. 85-108.

"La revolución militar de México: estrategias, tácticas y logísticas durante la guerra de independencia, 1810-1821”, en VÁzQUEZ (coord.), I997, pp. 123-176.

Brading, David

Los orígenes del nacionalismo mexicano, México, Era, 1995.

BREÑA, Roberto

"The Emancipation Process in New Spain and the Cadiz Constitution: New Historiographical Paths Regarding the Revoluciones Hispánicas", en Sobrevilla e Eastman (eds.), 2015, pp. 42-62.

"La Historia de Toreno y la historia para Toreno: el pueblo, España y el sueño de un liberal", en Historia Constitucional (revista electrónica), n. 13, 2012. http://www.historiaconstitucional.com/index.php/historiaconstitucional/article/ view/350/314

"Límites del constitucionalismo del liberalismo y hispánicos. Una visión crítica desde/sobre la historiografía actual”, en Rojas, Mijangos y Luna (coords.), 2012, pp. 47-66.

"Liberalismo y republicanismo durante las independencias americanas: un deslinde imposible”, en Olveda (ed.), 2012, pp. 33-51.

El primer liberalismo español y los procesos de emancipación de América, 1808-1824 (Una revisión historiográfica del liberalismo hispánico), México, El Colegio de México, 2006. 
El imperio de las circunstancias (Las independencias hispanoamericanas y la revolución liberal española), Madrid, Marcial Pons, El Colegio de México, 2012.

"The Cadiz Liberal Revolution (1810-14) and Spanish American Independence: The mundo bispánico in the Age of Revolution", en Tutino (ed.) [en prensa].

"Reseña de We Are Now The True Spaniards", en The Hispanic American Historial Review, 95:1 (feb. 2015), pp. 157-159.

Bustamante, Carlos María de

Juguetillo, México, Condumex, 1987.

Cos, José María

Escritos políticos, México, Universidad Nacional Autónoma de México, 1967.

Chartier, Roger et al.

La Revolución francesa: ¿matriz de las revoluciones?, México, Universidad Iberoamericana, 2010.

Chust, Manuel y José Antonio Serrano

“Guerra, revolución y liberalismo en México 1808-1835”, en Frasquet (coord.), 2006, pp. 151-199.

“Nueva España versus México: historiografía y propuestas de discusión sobre la Guerra de Independencia y el Liberalismo doceañista", en Revista Complutense de Historia de América, vol. 33, 2007, pp. 15-33.

Durán López, Fernando, Marieta Cantos Casenave y Alberto Romero Ferrer (eds.)

La guerra de pluma, Cádiz, Publicaciones de la Universidad de Cádiz, 2001-2008, 3 volúmenes.

Durán López, Fernando y Elisabel Larriba (eds.)

El nacimiento de la libertad de imprenta (Antecedentes, promulgación y consecuencias del Decreto de 10 de noviembre de 1810), Madrid, Ediciones Sílex, 2012. 
ElLiotT, John

Imperios del mundo atlántico (España y Gran Bretaña en América, 1492-1830), Madrid, Taurus, 2006.

Fernández de Lizardi, José Joaquín

El laberinto de la utopía (una antología general), México, Fondo de Cultura Económica, Universidad Nacional Autónoma de México, 2006.

Fontana, Josep

La quiebra de la monarquía absoluta, 1814-1820, Barcelona, Ariel, 1987.

Frasquet, Ivana (coord.)

Bastillas, cetros y blasones, Madrid, Mapfre, 2006.

Gómez Álvarez, Cristina

"El liberalismo en la insurgencia novohispana: de la monarquía constitucional a la república, 1810-1814”, en Secuencia, 89 (mayo-ago. 2014), pp. 9-26.

Granados, Luis Fernando

"Independencia sin insurgentes. El bicentenario y la historiografía de nuestros días”, en Desacatos, 34 (sep.-dic. 2010), pp. 11-26.

Guedea, Virginia

En busca de un gobierno alterno: los Guadalupes de México, México, Universidad Nacional Autónoma de México, 1992.

Guerra, François-Xavier

"La independencia de México y las revoluciones hispánicas", en Annino y Buve (coords.), 1993, pp. 15-48.

Hamill, Hugh

The Hidalgo Revolt, Gainsville, University of Florida Press, 1966. 
HamnetT, Brian

Raíces de la insurgencia en México (Historia regional, 17501824), México, Fondo de Cultura Económica, 2010.

HébRARD, Véronique y Geneviève VERDo (eds.)

Las independencias hispanoamericanas (Un objeto de bistoria), Madrid, Casa de Velázquez, 2013.

Hernández y Dávalos, Juan E.

Historia de la guerra de Independencia de México, México, Instituto Nacional de Estudios Históricos sobre la Revolución Mexicana, 1985, t. II.

Herrejón, Carlos

Hidalgo (Maestro, párroco e insurgente), México, Fomento Cultural Banamex, Clío, 2011.

HobsBawm, Eric

Echoes of the Marsellaise (Two Centuries Look Back on the French Revolution), Nueva Jersey, Rutgers University Press, 1990.

Iturbide, Agustín de

Manifiesto al mundo, o sean, Apuntes para la historia, México, Fideicomiso Teixidor, Libros del Umbral, 2001.

JudT, Tony

El peso de la responsabilidad (Blum, Camus, Aron y el siglo XX francés), Madrid, Taurus, 2014.

La Parra, Emilio

Los cien mil bijos de San Luis (El ocaso del primer impulso liberal en España), Madrid, Síntesis, 2007.

LARroche, Emmanuel

L'expédition d'Espagne (1823: De la guerre selon la Charte), Rennes, Presses Universitaires de Rennes, 2013. 
Lemoine, Ernesto (ed.)

Morelos (Su vida revolucionaria a través de sus escritos y de otros testimonios de la época), México, Universidad Nacional Autónoma de México, 1965.

Morange, Claude

Una conspiración fallida y una Constitución nonnata, 1819, Madrid, Centro de Estudios Políticos y Constitucionales, 2006.

Olveda, Jaime

De la insurrección a la independencia (La guerra en la región de Guadalajara), Zapopan, El Colegio de Jalisco, 2011.

Olveda, Jaime (coord.)

Independencia y Revolución (Reflexiones en torno del bicentenario y el centenario), Zapopan, El Colegio de Jalisco, 2012, vol. IV.

Ortiz Escamilla, Juan

Guerra y gobierno (Los pueblos y la independencia de México, 1808-1825), segunda edición corregida y aumentada, México, El Colegio de México, Instituto de Investigaciones Dr. José María Luis Mora, 2014.

Palazón Mayoral, María Rosa

“Una bella persona utópica”, en Fernández de Lizardi, 2006, pp. 15-49.

Paquette, Gabriel

"Introduction: Liberalism in the Early Nineteenth-century Iberian World”, en History of European Ideas, 41: 2 (2015), pp. 153-165.

Rodríguez O., Jaime E.

"Nosotros somos abora los verdaderos españoles" (La transición de un reino de la Monarquía Española a la República 
Federal de México, 1808-1824), México, El Colegio de Michoacán, Instituto de Investigaciones Dr. José María Luis Mora, 2009, 2 vol.

"We Are Now the True Spaniards": Sovereignty, Revolution, Independence, and the Emergence of the Federal Republic of Mexico, 1808-1824, Stanford, Stanford University Press, 2012.

Rodríguez O., Jaime E. (ed.)

The Independence of Mexico and the Creation of the New Nation, Los Angeles, Irvine, ucla Latin American Center, Mexico-Chicano Program, 1989.

SÁnchez-Mejía, María Luisa

"Repúblicas monárquicas y monarquías republicanas. La reflexión de Sieyès, Necker y Constant sobre las formas de gobierno", en Revista de Estudios Políticos (Nueva época), 20 (abr. 2003), pp. 195-217.

Serrano, José Antonio

"Deshaciendo el consenso. La historiografía sobre el proceso de independencia de la Nueva España, 1953-1997", en Mexican Studies, 29: 1 (invierno 2013), pp. 120-148.

Serrano, José Antonio (coord.)

El sexenio absolutista, los últimos años insurgentes (Nueva España, 1814-1820), Zamora, El Colegio de Michoacán, 2014.

Sobrevilla, Natalia y Scott Eastman (eds.)

The Rise of Constitutional Government in the Iberian Atlantic World, Tuscaloosa, University of Alabama Press, 2015.

Ternavasio, Marcela

Gobernar la revolución (Poderes en disputa en el Río de la Plata 1810-1816), Buenos Aires, Siglo Veintiuno editores, 2007.

Thibaud, Clément

"Les trois républiques de la Terre Ferme", en Hébrard y VerDO (eds.), 2013, pp. 245-257. 
Toreno, Conde de

Historia del levantamiento, guerra y revolución de España, Pamplona, España, Urgoiti Editores, 2008.

Tutino, John (ed.)

New Countries in the Americas: Diverging Paths to the World of Nations and Industrial Capitalism, 1750-1870, Durham, Duke University Press [en prensa].

URIBE-URÁn, Victor M. (ed.)

State and Society in Spanish America during the Age of Revolution, Wilmington, SR Books, 2001.

VAN Young, Eric

"La época de la revolución atlántica: comparaciones entre México, Estados Unidos y Francia”, en Chartier et al., 2010, pp. 225-274.

La otra rebelión (La lucha por la independencia de México, 1810-1821), México, Fondo de Cultura Económica, 2006.

"Was there an Age of Revolution in Spanish America?", en URIBE-URÁN (ed.), 2001, pp. 219-246.

Varela Suanzes, Joaquín

"La Constitución de Cádiz y el liberalismo español del siglo xIX", en Política y Constitución en España, 1808-1978, Madrid, Centro de Estudios Políticos y Constitucionales, 2007, pp. 45-108.

VÁzquez, Josefina Zoraida (coord.)

Interpretaciones de la independencia de México, México, Nueva Imagen, 1997. 